\title{
Survey of Tick Infestation in Domestic Ruminants of Haramaya District, Eastern Hararghe, Ethiopia
}

\section{Tsegaw Desalegn, Abraham Fikru and Surafel Kasaye*}

School of Veterinary Medicine, Hawassa University, P. O. Box 5, Hawassa, Ethiopia

*Corresponding author: Surafel Kasaye, School of Veterinary Medicine, Hawassa University, P. O. Box 5, Hawassa, Ethiopia, Tel: 0201113532752; E-mail: surafelkasaye325@gmail.com

Received date: June 21, 2015; Accepted date: October 09, 2015; Published date: October 13, 2015

Copyright: ( 2015 Desalegn T et al. This is an open-access article distributed under the terms of the Creative Commons Attribution License, which permits unrestricted use, distribution, and reproduction in any medium, provided the original author and source are credited.

\begin{abstract}
A survey was conducted to determine the prevalence of tick infestation and to identify tick species in domestic ruminants (cattle, sheep and goat) in Adelle, Batte, Tuji-gabisa and Ifa-Oromia kebeles of Haramaya district of Eastern Hararghe, Oromia region. Collection and identification of the ticks were undertaken from November 2013 to March 2014. All visible individual adult ticks were collected from half body part of 265 cattle, and whole body part of 198 sheep and 150 goats. The prevalence of tick infestation in cattle, sheep and goats was found to be $25.23 \%$, $10.1 \%$ and $10 \%$, respectively. The most abundant species found in this study were Boophilus decoloratus (47.8\%), Amblyomma variegatum (28.4\%) and Amblyomma gemma (12.48\%), whereas, Rhipicephalus pulchellus (9.3\%), Rhipicephalus evertsi evertsi (2.02\%). Rhipicephalus evertsi evertsi is the minor species of tick observed on cattle and sheep and none of these ticks were recorded in goats in the study area. Rhipicephalus pulchellus was observed only on cattle and none of these ticks were recorded in sheep and goats. The difference in the prevalence of tick infestation between species and age was statistically significant $\left(X^{2}=25.143, P=0.000\right.$ and $\left.X^{2}=21.806, P=0.000\right)$ respectively. But sex, breed, locality and body condition were not statistically significant $(P>0.05)$. The adult male ticks were more prevalent than the number of adult female ticks except for Boophilus decoloratus the reverse was true. Since they cause severe damage to the hides and skins of domestic ruminants and thereby reduce the foreign exchange of the country; they also transmit tick borne diseases, effective tick control programs should be formulated and implemented in the national or regional level.
\end{abstract}

Keywords: Domestic ruminants; Haramaya district; Tick; Survey

\section{Introduction}

In Ethiopia, ticks and tick borne diseases cause considerable losses to the livestock economy, ranking third among the major parasitic disasters, after trypanosomes and endoparasitism. Ticks are harmful blood sucking external parasites of mammals, birds and reptiles throughout the world [1]. The main ticks found in Ethiopia belong to genus Amblyomma, Boophilus, Haemaphysalis, Hyalomma and Rhipicephalus [2].

In addition to transmitting certain protozoan, rickettsial and viral diseases, ticks also predispose animals to secondary bacterial infections [3]. Tick damage hides and skins and interfere with meat and milk production. The most commonly known tick born diseases are anaplasmosis, babesiosis, theileriosis and heart water; ticks also cause non-specific symptoms like anemia, dermatitis, toxicosis and paralysis [4]. Ticks also resulted an estimated annual loss of US $\$ 500000$ from hide and skin downgrading and approximately $65.5 \%$ of major defects of hides in Eastern Ethiopia [2].

Even though some preliminary research work on the tick infestation was carried out in Eastern parts of Ethiopia, detail investigations directed towards a species level identification and the identification of its risk factors at Haramya district was not well studied. Hence, determination of tick species and its prevalence in the area is very critical for the diagnosis of different tick borne diseases and their respective control programs in Ethiopia. Therefore, the objectives of the present study were to determine the prevalence of tick infestation in the study area, and identify tick species and major risk factors for the occurrence of tick infestation.

\section{Materials and Methods}

\section{Study area}

The study was conducted in Adelle, Batte, Tuji-gabisa and IfaOromia kebele of Haramaya district of Eastern Hararghe, Oromia region. The district is located $508 \mathrm{~km}$ East of Addis Ababa. Topographically, it is situated at an altitude of 1600 to $2100 \mathrm{~m}$ above sea level at $9^{\circ} 26^{\prime} \mathrm{N}$ latitude and $42^{\circ} 3^{\prime} \mathrm{E}$ longitudes with the mean annual temperature and relative humidity of $18^{\circ} \mathrm{C}$ and $68 \%$, respectively. Small holder mixed farming system is the dominant mode of production of the farmers in the area. The district has about 76,336 cattle, 65,083 sheep, and 84,916 goats, 22,355 donkeys, 356 camels and 89,800 chickens. The area receives an average annual rain fall of approximately $900 \mathrm{~mm}$, with a bimodal distribution pattern [5].

\section{Study design and sampling strategy}

A cross-sectional study was conducted on domestic ruminants (Cattle, Sheep and Goats) of both sex and different age groups, body condition, locality, and breed in Haramaya district, from November 2013 to March 2014. A simple random sampling method was used to select study animals from selected four kebeles. These locations were selected according to abundance availability of animals and geographical location difference. The sample size was determined according to Thrusfield [6] for an infinite population with $95 \%$ 
Page 2 of 4

confidence interval, $5 \%$ desired absolute precision by considering the expected prevalence to be $50 \%$. The sample size was calculated as 384 domestic ruminants (cattle, sheep and goats). However, maximum effort was used to increase sample size. Accordingly a total of 613 ruminants were examined which comprises 265 cattle, 198 sheep and 150 goats.

\section{Study methodology}

Before tick collection, the animals were properly casted down and restrained properly. The adult engorged visible ixodid ticks were removed carefully and gently in a horizontal pull to the body surface by hand from whole body side in sheep and goats and from half body part for cattle. The collected ticks from different predilection site were preserved in universal bottles containing $70 \%$ ethyl alcohol as a preservative for each species of animals. The universal bottles were properly labelled with sex of the host and species of animals before collection done and transported to the laboratory where the ticks were identified.

The collected ticks were placed in to a petridish and allowed to spread on filter paper to absorb excess preservative. First, ticks were seen grossly and classified to different genera levels. Ticks were identified into their species level depending up on their morphology and identification structures they have, such as shape of scutum, leg color, body, coxae one and ventral plates. Counting and identification to genus and species level were carried out using a standard stereomicroscope based on tick identification key adopted by Walker et al. [2].

\section{Data management and analysis}

The data collected were entered and managed in Microsoft excel. The analysis was made using SPSS 20.1 software package. The prevalence of tick was determined by dividing the number of positive samples by the total sample size, and was expressed as percentages. Chi-square $\left(\mathrm{X}^{2}\right)$ was used to assess if there was a statistically significant difference in tick infestation with in different species, age, body condition, breed, and locality and sex groups. For this analysis, pvalues less than 0.05 were considered as significant.

\section{Results}

Of the total 613 examined domestic ruminants, $16.64 \%$ were infested by one or more tick species. The corresponding percentage of infestation in cattle, sheep and goat was $25.23 \%, 10.1 \%$ and $10 \%$, respectively (Table 1). Examined animals were considered to be positive for a given tick infestation when at least one tick was collected from them. The difference in the prevalence of tick infestation was found to be statistically significant between the three species of animals and age groups $(\mathrm{P}=0.000)$. However, the difference was not significant between different sex, breed, locality, and body condition groups ( $\mathrm{P}>0.05)$. Overall, a total of 1042 ticks were collected from 265 Cattle, 198 Sheep and 150 goats. From the total count, Boophilus decoloratus was the dominant tick species (47.8\%) and Rhipicephalus evertsi evertsi $(2.02 \%)$ was the least (Table 2 ).

Up on identification, the ticks were classified into three genera and five species. (Table 3) Overall, total of 1042 ticks collected from 265 Cattle, 198 Sheep and 150 goats, 3 genera and 5 species were identified, of which Boophilus accounts for 498 (47.8\%), Amblyomma 426 (40.8\%) and Rhipicephalus 118 (11.33\%). Boophilus decoloratus was the most abundantly encountered with high burden followed by
Amblyomma variegatum, Amblyomma gemma, Rhipicephalus pulchellus and Rhipicephalus evertsi evertsi. Whereas, Rhipicephalus evertsi evertsi was less frequently encountered observed in Cattle and Sheep and it was not recorded in goats. On the other hand, Rhipicephalus pulchellus was observed only in cattle (Table 3). In this study male tick count dominated females except for Boophilus decoloratus (Table 4).

\begin{tabular}{|c|c|c|c|c|}
\hline Variables & Category & $\begin{array}{l}\text { Number } \\
\text { examined }\end{array}$ & $\begin{array}{l}\text { Number }(\%) \text { found } \\
\text { to be infested }\end{array}$ & Significance \\
\hline \multirow[t]{3}{*}{ Species } & Cattle & 265 & $67(25.23)$ & \multirow{3}{*}{$\begin{array}{l}X^{2}=25.143 \\
P=0.000\end{array}$} \\
\hline & Sheep & 198 & $20(10.1)$ & \\
\hline & Goat & 150 & $15(10)$ & \\
\hline \multirow[t]{2}{*}{ Sex } & Female & 319 & $60(18.8)$ & \multirow{2}{*}{$\begin{array}{l}X^{2}=2.257 \\
P=0.133\end{array}$} \\
\hline & Male & 294 & $42(14.23)$ & \\
\hline \multirow[t]{2}{*}{ Breed } & Local & 588 & $95(16.16)$ & \multirow{2}{*}{$\begin{array}{l}X^{2}=2.425 \\
P=0.119\end{array}$} \\
\hline & Cross & 25 & $7(28)$ & \\
\hline \multirow[t]{4}{*}{ Locality } & Adelle & 140 & $21(15)$ & \multirow{4}{*}{$\begin{array}{l}X^{2}=0.902 \\
P=0.825\end{array}$} \\
\hline & Batte & 135 & $25(18.52)$ & \\
\hline & Ifa-Oromia & 140 & $25(17.86)$ & \\
\hline & Tuji-gabisa & 198 & $31(15.67)$ & \\
\hline \multirow[t]{3}{*}{ Age } & $\leq 1$ year & 46 & $0(0)$ & \multirow{3}{*}{$\begin{array}{l}X^{2}=21.806 \\
P=0.000\end{array}$} \\
\hline & Years & 318 & $40(12.58)$ & \\
\hline & $\geq 3$ years & 249 & $62(24.9)$ & \\
\hline \multirow[t]{3}{*}{ BCS } & Good & 123 & $17(13.8)$ & \multirow{3}{*}{$\begin{array}{l}X^{2}=2.648 \\
P=0.266\end{array}$} \\
\hline & Medium & 430 & $71(16.5)$ & \\
\hline & Poor & 60 & $14(23.3)$ & \\
\hline
\end{tabular}

Table 1: Overall prevalence of tick infestation in domestic ruminants (cattle, sheep and goat).

\begin{tabular}{|l|l|}
\hline Tick species & Total Count (\%) \\
\hline Boophilus decoloratus & $498(47.8)$ \\
\hline Amblyomma variegatum & $296(28.4)$ \\
\hline Amblyomma gemma & $130(12.48)$ \\
\hline Rhipicephalus pulchellus & $97(9.3)$ \\
\hline Rhipicephalus evertsi evertsi & $21(2.02)$ \\
\hline
\end{tabular}

Table 2: Relative abundance of tick species during the study period.

\section{Discussion}

The distribution and abundance of tick species infesting domestic ruminants in Ethiopia vary greatly from one area to another area. In this study, Boophilus decoloratus were found to be the most prevalent (47.8\%) tick species in Haramaya district. This is in agreement with previous report [7] with highest prevalence (30\%) of Boophilus 
Page 3 of 4

decoloratus in Humbo district, SNNPR, Ethiopia. This result disagree with the findings at Metekel Ranch [8], showing prevalence of $5.7 \%$ and in Asela reported the highest prevalence of (80\%) for Boophilus decoloratus [9]. This may be due to the geographical location and altitude factors which govern the distribution of ticks in the study area.

\begin{tabular}{|l|l|l|l|l|}
\hline Tick species & Cattle $(\mathbf{n = 2 6 5 )}$ & Sheep $(\mathbf{n = 1 9 8 )}$ & $\begin{array}{l}\text { Goat } \\
\mathbf{( n = 1 5 0 )}\end{array}$ & $\begin{array}{l}\text { Overall } \\
\text { prevalence }\end{array}$ \\
\cline { 2 - 5 } & Positive (\%) & Positive (\%) & Positive (\%) & $\begin{array}{l}\text { Positive } \\
(\%)\end{array}$ \\
\hline $\begin{array}{l}\text { Boophilus } \\
\text { decoloratus }\end{array}$ & $30 / 265(11.32)$ & $12 / 198(6.06)$ & $\begin{array}{l}10 / 150 \\
(6.67)\end{array}$ & $\begin{array}{l}52 / 613 \\
(8.48)\end{array}$ \\
\hline $\begin{array}{l}\text { Amblyomma } \\
\text { variegatum }\end{array}$ & $31 / 265(11.7)$ & $6 / 198(3.03)$ & $3 / 150(2.00)$ & $\begin{array}{l}40 / 613 \\
(6.52)\end{array}$ \\
\hline $\begin{array}{l}\text { Amblyomma } \\
\text { gemma }\end{array}$ & $9 / 265(3.34)$ & $5 / 198(2.52)$ & $4 / 150(2.67)$ & $\begin{array}{l}14 / 613 \\
(2.28)\end{array}$ \\
\hline $\begin{array}{l}\text { Rhipicephalus } \\
\text { pulchellus }\end{array}$ & $9 / 265(3.34)$ & $0 / 198(0.00)$ & $0 / 150(0.00)$ & $\begin{array}{l}9 / 613 \\
(1.47)\end{array}$ \\
\hline $\begin{array}{l}\text { Rhipicephalus } \\
\text { evertsi evertsi }\end{array}$ & $5 / 265(1.89)$ & $1 / 198(0.50)$ & $0 / 150(0.00)$ & $\begin{array}{l}6 / 613 \\
(0.98)\end{array}$ \\
\hline
\end{tabular}

Table 3: Species-level prevalence of tick infestation in domestic ruminants (cattle, sheep and goat).

\begin{tabular}{|l|l|l|l|}
\hline Tick species & $\begin{array}{l}\text { Male tick } \\
\text { count }\end{array}$ & Female tick count & $\begin{array}{l}\text { Male: } \\
\text { Female ratio }\end{array}$ \\
\hline Boophilus decoloratus & 48 & 450 & 0.107 \\
\hline Amblyomma variegatum & 232 & 64 & 3.63 \\
\hline Amblyomma gemma & 100 & 30 & 3.34 \\
\hline Rhipicephalus pulchellus & 81 & 16 & 5.06 \\
\hline $\begin{array}{l}\text { Rhipicephalus evertsi } \\
\text { evertsi }\end{array}$ & 18 & 3 & 6 \\
\hline
\end{tabular}

Table 4: Total and average tick burden in the domestic ruminants (Cattle, Sheep and Goat).

The prevalence of tick in cattle was found to be $25.23 \%$ and it is different from the findings of [10] who reported an overall prevalence of $89.4 \%$ in Western Amhara. The result also disagrees with the findings in Humbo district, Southern nation's nationalities with $61 \%$ prevalence [7]. This difference could be due to temperature, rainfall pattern and altitude that influence the occurrence of ticks in the areas. The prevalence of tick in sheep (10.1\%) slightly lower than the works conducted in North East Ethiopia who reported (22.2\%) [11] and in Western Shoa zone central Ethiopia who reported 22.5\% in sheep [12]. The prevalence of tick in goat $(10 \%)$ is slightly higher than $(3.4 \%)$ prevalence report in North East Ethiopia [11] and in western Shoa zone central Ethiopia who reported (6.3\%) for goat [12]. However, it is highly different from the report of $89.9 \%$ prevalence of tick in sheep and $87.5 \%$ in goats at Miesso district of Oromia regional state [13]. The difference in the prevalence might be due to the geographical difference, season of the study periods management condition and control strategies in the study sites.

In all cases, except for Boophilus decoloratus, males outnumbered females; this is most probably because fully engorged female ticks drop off to the ground to lay eggs while males tend to remain on the host up to several months later to continue feeding and mating with other females on the host before dropping off [14-16]. Host grooming easily remove semi-engorged or engorged females as compared to males [14]. The females of Boophilus decoloratus outnumbered males in this study probably due to the small size of the male which could not be seen. This might be one of the contributory factors for missing males. Similar report was indicated $[4,17,18]$.

Higher prevalence was recorded in female animals (18.8\%) compared to male (14.23\%). This variation may be associated with male animals which were kept properly in the house with good management system for beef purpose whereas, female animals grazing on field all day may be exposed to tick infestation. This result disagreed with higher prevalence report in males [19].

More tick prevalence was recorded in cross breed (28\%) compared to local animals (16.16\%). This result is in agreement with higher prevalence report in cross breed when compared to local [20]. In contrast, other report revealed that the presence of tick infestation in local breeds were very high with the prevalence of $44.96 \%$, while in cross breeds $15.83 \%$ prevalence [21]. The significant variation in tick infestation of animals of different breeds in their research might be attributed to different management system, lack of supplementary feeding for local breeds, or lack of control measures against tick on local breeds. Furthermore, it can be assumed that it might be due to lack of interest of farmers for local breeds as well as taking more care to cross and exotic breeds than local breeds.

The proportion of tick infestation was higher in age groups greater than 3 years $(12.58 \%)$ as compared to less than 3 years $(14.9 \%)$. The higher proportion may be due to outdoor management and long distant movement of adult animals to search for food and water compared to younger animals, so the chance of exposure is higher. This finding is also in agreement with a higher proportion in adult animals [20-22].

The proportion of tick infestation was higher in poor body conditioned $(23.3 \%)$ as compared to medium body conditioned (16.5\%) and good body conditioned animals (13.8\%). This was due to the fact that poor body condition scored animals have reduced resistance to tick infestation and lack of enough body potential to build resistance so, they are exposed to any kind of disease when grazing on the field, and medium body conditioned animals were free ranging and relatively resistant to disease, so they become less infested than poor sized animals but the well fed animals were very resistant to any kind of diseases when they grazed in the field or kept home. This was contrary the findings of higher prevalence of tick infestation in medium body conditioned $(79.78 \%)$ as compared to poor body conditioned (67.86\%) and good body conditioned animals (58\%) [7].

\section{Conclusion}

The present study indicated that ticks infestation are highly prevalent in cattle, sheep and goat in the study areas that might be used for tick control program where species and age were significantly associated with prevalence of tick infestation. Boophilus decoloratus were found to be the most prevalent tick species. Since tick cause severe damage to the hides and skins of domestic ruminants and thereby reduce the foreign exchange of the country; they also transmit tick borne disease which can cause severe loss to the productivity of these animals. In order to reduce and avoid losses incurred by ticks, 
Citation: Desalegn T, Fikru A, Kasaye S (2015) Survey of Tick Infestation in Domestic Ruminants of Haramaya District, Eastern Hararghe, Ethiopia. J Bacteriol Parasitol 6: 246. doi:10.4172/2155-9597.1000246

Page 4 of 4

effective tick control programs should be formulated and implemented in the national or regional level.

\section{Acknowledgements}

We are grateful to Hawassa University, School of veterinary medicine for supporting this research work.

\section{References}

1. Rajput ZI, HU SH, Chen WJ, Arijo AG, Xiao CW (2006) Importance of tick and their chemical and immunological control in livestock. J Zhejiang Univ Sci 7: 912-921.

2. Walker AR, Bouattour A, Camicas GR, Estrada-Pena A, Horak IG, et al. (2003) Ticks of Domestic Animals in Africa. A guide to identification of species. International Consortium on tick and tick born diseases.

3. Bekele T (2002) Studies on seasonal dynamics of ticks of Ogaden cattle and individual variation in resistance to ticks in Eastern Ethiopia. J Vet Med Ser B 49: 285-288.

4. Solomon G, Night M, Kassa B (2001) Seasonal variation of tick on calves at Sebeta in Western Shewa Zone, Ethiopia. Ethiopian Vet J 7: 17-30.

5. Physical and Socio-Economic Profile of East Hararge Zone (2010) Finance and Economic Development Office of East Hararge Zone, Harar, Ethiopia.

6. Thrusfield M (1995) Veterinary Epidemiology (2ndedn.) Black well Science Ltd., UK, pp. 182-189.

7. Wasihun P, Doda D (2013) Study on the prevalence and identification of ticks in Humbo district, SNNPR, Ethiopia. Journal of veterinary medicine and Animal Health 5: 73-80.

8. Alekaw S (2000) Distribution of tick and tick born diseases at metekel ranch. Ethiopian veterinary Journal 4: 40-60.

9. Tamru T (2008) Survey of Bovine tick species in and around Asela Town, DVM Thesis, School of Veterinary Medicine, Jimma University, Jimma, Ethiopia.

10. Nigatu K, Teshome F (2012) Population dynamics of cattle ectoparasites in Western Amhara National Regional State, Ethiopia. J Vet Med Anim Health 4: 22-26.
11. Sertse T, Wossene A (2007) A study on ectoparasites of sheep and goats in eastern part of Amhara region, North east Ethiopia. Small Ruminant Research 69: 62-67.

12. Zeryehun T, Atomsa M (2012) Ectoparasiotes infestations of sheep and goats. Eurasian Journal of veterinary science 28: 185-189.

13. Abuna F, Kasasa D, Shelima B, Megersa B, Regassa A, et al. (2009) Survey of tick infestation in small ruminants of Miesso district, West Hararghe Oromia region, Ethiopia. Trop Animal Health prod 41: 969-972.

14. Solomon G, Kaaya GP, Gebreab F, Gemetchu T, Tilahun G (1998) Ticks and tick borne parasites associated with indigenous cattle in Did-tuyura ranch, Southern Ethiopia. Ins Sci Applic 18: 59-66.

15. Minjauw B, Mcleod A (2003) Tick borne disease and poverty. The impact of tick and tick borne disease on the livelihood of small scale and marginal Livestock Owner in India and Eastern Southern Africa research report. DFID animal health program centre for tropical veterinary medicine, University of Edinburgh, UK.

16. Abebaw G (2004) Seasonal dynamics and host preference of Boophilus decoloratus on naturally infested cattle in Jimma Zone, South Western Ethiopia. Ethiopia Vet J 18: 19-28.

17. Shiferaw D (2005) Cattle tick dynamics in different agro-ecological zone of Soddo, Southern Ethiopia. MSc Thesis, faculty of veterinary medicine. Addis Ababa, Ethiopia, pp. 15-85.

18. Abebaw G, Tamiru T (2010) Prevalence of ticks on local and crossbred cattle in and around Asella town, Southeast Ethiopia. Ethiopian Veterinary Journal 14: 79-89.

19. Hussen Y (2009) Preliminary survey of cattle tick species and burden in and around Bako Town. DVM Thesis, school of Veterinary Medicine Jimma University, Jimma, Ethiopia.

20. Tessema T, Gashaw A (2010) Prevalence of ticks on local and crossbreed cattle in and around Asela Town, South East, Ethiopia. Ethiopia Vet J 14: 79-89.

21. Belew T, Mekonnen A (2011) Distribution of Ixodidae ticks on cattle in and around Holeta Town, Ethiopia. Global veterinaria 7: 527-531.

22. Feseha B (1997) Species composition and distribution of Ixodid tick in Eastern Hararghe, Ethiopia. Agric Sci 16: 37-51. 